\title{
O NOVO TITULAR, PROFESSOR CARLOS ALBERTO BITTAR, PROFERE SEU DISCURSO DE POSSE
}

Excelentíssimo Senhor Professor Antonio Junqueira de Azevedo, DD. Diretor da Faculdade de Direito da USP, cuja atuação, firme e decidida, tornou possíveis a renovação do quadro docente da nossa gloriosa Academia e as solenidades que ora se realizam;

Excelentíssimo Senhor Yussef Said Cahali, que muito me honrou com sua brilhante saudação;

Senhores Professores, Magistrados, Alunos, Funcionários, Familiares, que sempre me incentivaram:

Investido na função de Professor Titular, na área de Direito de Autor, entendi que melhor exprimiria minha alegria falando sobre a extraordinária identificação entre nossa Faculdade e o Direito em questão, desde o seu nascedouro até os dias presentes e daqui para a eternidade.

Homenageio, assim, de um lado, a inteligência universal, que ungiu e imprimiu cor a esse fascinante campo de investigação científica, que é o Direito de Autor e, de outro, esse cenáculo nacional de formação e de concentração de valores exponenciais de nossa civilização, que é a Faculdade de Direito.

Com efeito, nossa Academia nasceu sob o signo do Direito de Autor, a atestar sua quase bicentenária tradição privatista, de irrestrita defensora de direitos essenciais da personalidade humana, como se pode verificar no próprio texto de sua instituição, que se acha, aliás, insculpido nas significativas paredes da Sala da Congregação. Assim, está escrito, na Lei que, sob a égide do Visconde de São Leopoldo, em 11.8.1827, criou os Cursos Jurídicos, de São Paulo e de Olinda (art. $7^{\circ}$ ), que os "lentes farão a escolha dos compêndios de sua profissão, ou os arranjarão, não existindo já feitos" e depois de aprovados seriam publicados, "competindo aos seus autores o privilégio exclusivo da obra, por dez anos" Ora, com a expressão privilégio, que vem do Direito Medieval, consagrou-se ali o direito 
autoral dos mestres, como estímulo para a produção literária e a conseqüente instrução intelectual das gerações de então. Ora, nessa linha, trabalhos de enorme vulto foram realizados e ora enaltecem nossa literatura jurídica, muitos dos quais ornam ainda nossa Biblioteca e nossos arquivos.

Agora, com o reconhecimento do Direito de Autor como área autônoma de estudos, no plano maior do Direito Privado, vem a Faculdade resgatar débito que tinha para com tão relevantíssimo ramo do Direito e, ao mesmo tempo, mantendo sua imorredoura condição de liderança, assumir posição de vanguarda nos meios intelectuais das Américas, pois se trata da primeira Faculdade a dispor de seara própria para o cultivo desse precioso produto cultural, ao qual está reservada a condução dos caminhos do homem no século que se aproxima, em razão da conjugação do binômio criatividade-tecnologia como epicentro do desenvolvimento geral.

De fato, a interligação entre os povos pela telemática; a expansão de redes eletrônicas de transmissão, que permitem a difusão em segundos, de obras intelectuais; os diferentes mecanismos de reprodução e de representação vem conferindo dimensões jamais imaginadas à comunicação humana, que, como se sabe, tem em sua base, o Direito de Autor, disciplinando todas as relações jurídicas decorrentes da criação e do uso de suas obras.

Assim, ontem, quando de sua criação, ébrios de saber, os intelectuais brasileiros exigiam uma Universidade; quiseram seus instituidores que ficasse gravada, em letras imorredouras, a mensagem autoralista a identificar e a unir criador e criação no domínio das letras, das ciências e das artes. Hoje, que o mundo assiste, deslumbrado, ao estreitamento das relações entre os povos através da linguagem eletrônica que aos poucos substitui a comunicação pessoal nossa Academia abre, com descortínio e com sabedoria, campo próprio para pesquisas e para estudos de Direito de Autor, sob cujo comando se acham intelectuais e pensadores, artistas e cientistas, enfim, homens que, com seus escritos, com seus engenhos e com seus aparatos sofisticados, mudam a face da Terra. Ora, nos dois pólos está assim nossa Faculdade, a demonstrar sua irresistivel vocação para o comando intelectual de nossa gente.

É, aliás, sob essa fulgurante e sólida matriz que se cunhará o relacionamento do porvir, onde homens e máquinas caminharão juntos, sob um 
princípio fundamental, que advém do direito natural, o princípio do suum cuique tribuere. Nesse ponto é necessário que se evidencie que, a final, é no direito natural que, desde Aristóteles a Cícero, de Santo Agostinho a Santo Tomás, de Grotius a Leão XIII, se abeberam, ao longo dos séculos, os cultores da Arte do Direito Privado, origem, fundamento e cerne de todos os direitos ora reconhecidos, desde a lapidar e eterna construção romana.

É que o Direito se volta para a proteção do homem na defesa de sua dignidade, a que se deve curvar o Estado, a lei, enfim, o Poder: não há Direito sem Homem, não há Homem sem Direito. Daí, as sábias palavras do legislador constituinte brasileiro de 1988, que, em nosso País, e em nossa Carta Magna, inscreveu a defesa dos valores sociais e individuais como meta fundamental de nosso Estado. É a vocação cristã do povo brasileiro, que encontra em Deus forças para o constante renovar e a busca do lugar de destaque que lhe está reservado no contexto das Nações.

Nessa busca devem estar presentes os valores morais, religiosos, sociais e individuais, que compõem a cultura brasileira, e que a inserem dentre as mais expressivas no cenário mundial. Testemunhando essa integração, estão, entre nós, os espíritos imortais de Tomás Antonio Gonzaga, de Tobias Barreto, de Teixeira de Freitas, de Clóvis Beviláqua, de Eduardo Espínola, de Filadelfo Azevedo, e de outros tantos juristas e filósofos, que edificaram o direito brasileiro.

Lembramos, também, nesse iter, os inúmeros autoralistas, estrangeiros e nacionais, que, com seu talento e seu labor, elevaram aos píncaros do conhecimento mundial a doutrina e a prática do respeito que se deve ministrar aos direitos de criação, apregoados, desde tempos antigos, mas detectados com o advento do iluminismo. E aqui desfilam Héricourt, Laboulaye, Hervieu, Piola Caselli e outros tantos expoentes.

Mais se evidencia essa necessidade, quando se atenta para a extraordinária revolução que se processa nas comunicações. Com efeito, opera-se verdadeira integração dos meios de comunicação, através da informática, obtendose ora a inter-relação entre imagens, vozes, sons, gráficos e textos. Memórias e centros de dados são desenvolvidos, a partir do uso de máquinas e de aparelhos altamente sensíveis e miniaturizados. Produzem-se máquinas de fax, robôs, videofones e satélites, em que podem ser transmitidas e reproduzidas obras 
intelectuais protegidas. Terminal de multimídia aparelho em que se permite a fusão de três técnicas: computadores, telefonia celular e fibras óticas (de quartzo) está revolucionando o mundo das comunicações. Combinam-se vidro e luz, para a transmissão de dados (fibras óticas finíssimas, em vez de cobre), possibilitando-se a divulgação de enciclopédias inteiras em segundos, sem qualquer interferência e para grandes distâncias. A USP está, aliás, instalando o sistema para interligar suas unidades, fazendo-se a conexão por meio de telefone, conforme projetos já desenvolvidos nos EUA. O Brasil integrar-se-á em três regimes de caráter internacional até final de 1994. Chega-se, então, à chamada "super rodovia" de dados, com rede de computadores (internet), operando comunicações, sem fronteiras, de quaisquer obras do intelecto. Batalha-se, ainda, na consecução de máquinas que pensam e que trabalham (robôs inteligentes) e que substituirão o homem em diferentes e incalculáveis ações na vida normal de relações.

Esses incriveis avanços tecnológicos buscam alcançar, no século que se avizinha, dentre outros objetivos: a) o contato com possíveis habitantes do espaço, já preparado, na Terra, através do alinhamento de radiotelescópios, nos EUA, com o uso da denominada "freqüência mágica" em ondas de rádio lançadas no espaço à procura das chamadas "garrafas cósmicas" e suas mensagens; b) a constituição de verdadeiro "condomínio espacial" imaginado por Gerard O'Neil, em seu trabalho sobre a colonização do espaço, de 1974 (e, depois, cristalizado no livro The High Frontier), com a instalação de colônias humanas nos assim designados "pontos lagrangeanos" entre a Terra e a Lua, em que os corpos humanos podem restar em equilíbrio orbital (Programa Space Shutle); c) a dominação total das células humanas, no chamado Projeto Genoma, que a Engenharia Genética vem executando na perseguição da reprogramação humana, considerado o mais sofisticado instrumento da Biologia Molecular (que já decompôs o DNA, o ácido desoxirribonucleico, ou ácido da vida); d) a expansão da telemática para a consecução do robô inteligente imaginado por William Gibson, em 1984, em seu Neuromancer, ou computador pensante, na seqüência do atual computador "falante" ou "conversador". e após a total compreensão do pensamento humano, que poderá ser a revolução máxima do século XXI; e) desenvolvimento, nessa linha, da técnica de penetração no ciberespaço, para realização de viagens simuladas (aperfeiçoamento das ora existentes simulações de vôos e outras); f) a inserção de inúmeros novos aparatos tecnológicos, na mesma trilha, como os 
gadgets eletrônicos, robôs vários, videofones e outros mecanismos de comunicação, que, por permitir a reprodução e a representação de obras estéticas, interferem com o Direito do Autor.

Realce-se, nesse contexto, a fantástica evolução perpetrada pelo uso das referidas fibras óticas em que se combinam vidro (quartzo) e luz, para a transmissão de dados, sons, imagens, escritos e outras manifestações do engenho humano. Cogita-se da formação de autêntica "super rodovia" de dados que interligará, de início, os vários Estados da Federação norte-americana.

Outro ponto que toca, mais de perto, à área em questão é o da digitalização de documentos, já em uso nos EUA, no Japão e em certos países da Europa, que tem possibilitado a substituição de arquivos de papéis e de microfilmes. Realizando a reprodução da imagem de todo o documento, e não por linha, como no sistema tradicional, permite processamento de fotografias, desenhos, figuras, textos e outras obras intelectuais, inclusive com o acréscimo de voz humana. Os documentos são passados em scanners e, depois, armazenados em discos óticos, eliminando-se papéis, microfilmes ou microfibras e, com isso, simplificando a tarefa de arquivamento de dados, por instituições, empresas ou pessoas interessadas.

Anote-se, nesse passo, a constante diminuição de tamanho de computadores, telefones, aparelhos de som, de fax e outros aparatos eletrônicos (miniaturização), que faculta a abertura de espaço, à disposição dos interessados, em escritórios, fábricas, lojas, residências e em outros locais, públicos ou privados, em que podem ser instalados.

Por fim, os aparatos de multimídia são outros tantos dispositivos geradores de problemas na área autoral, porque também condutores de obras intelectuais, cuja proteção há que se fazer, através de sistema próprio, diante da necessidade de preservação da personalidade humana.

Ora, esses câmbios, que marcam o complexo mundo atual estão, assim, a apontar as vias por onde as relações humanas penetrarão. Podem-se desde logo anotar ou mesmo antever situações, como as de trocas comerciais eletrônicas; difusões de sons e de imagens por espaços sem fim; transmissão de textos inteiros em segundos; comunicações espaciais ou extraterrestres. Na era do conhecimento, os serviços dominarão o mundo negocial, substituindo a atual era industrial; o 
comércio avançará com o uso de aparatos eletrônicos; as comunicações centralizarão as atenções do mundo jurídico (cf. nossos textos "Autonomia Científica do Direito de Autor", em Revista de Direito Civil, 63/37, e "O Direito de Autor e o Impacto das Novas Tecnologias," em RT 701/13). Ora, em todos esses aspectos, imperará, soberana, a disciplina do Direito de Autor, a ditar princípios e normas que governarão as relações oriundas, seja da criação, seja da utilização de obras envolvidas nesse contexto, concretizando-se, assim, o necessário equilíbrio que as deve presidir.

Com efeito, a extraordinária evolução tecnológica, que vem interligando todo o mundo, terá sempre o comando do sistema autoral. Mas a crescente expansão está a exigir constantes meditações aos governantes e aos pensadores atuais, na perseguição de conceitos, de fórmulas e de soluções que possam conciliar, como de preceito, o natural crescimento dos meios de comunicação com a defesa intransigente dos direitos dos criadores. Põe-se então, em evidência, o talento, mas também se exige o labor dos autoralistas, na base de soluções compatíveis para os magnos problemas que estão por vir, amenizados, no entanto, pelos preciosos estudos que, periodicamente, dimanam da Organização Mundial da Propriedade Intelectual (OMPI), instituída através de Convenção, que congrega, atualmente, mais de 130 nações, constituindo-se, assim, na mais vasta rede de entrelaçamento jurídico do mundo. É que, nessa área, comungam todas as nações dos ideais de justiça e de equilibrio, que se acham incrustados no âmago do Direito de Autor, mas, voltados para o futuro, buscam incessantemente seu aperfeiçoamento, convictas de que representa ele, como o querem os franceses, "le droit le plus sacré de l'home", e, portanto, carente de vigilantes e contínuos cuidados.

Acompanhando essa expansão, estudando e pesquisando nesse campo estarão Mestres e Alunos da Casa ou de outros centros, que poderão contribuir para a necessária adequação dos interesses em jogo, sempre sob a chama que dessa augusta Faculdade emana, na qual, aliás, se podem sentir os eflúvios de nossa gloriosa origem coimbrã e, portanto, da mais pura tradição universitária ocidental.

E é essa tradição - que os jovens precisam conhecer e absorver - que norteará os passos de nossa entidade, mas atenta sempre para a realidade, e enlevada pela cultura, pelo esforço, pela dedicação e pelo trabalho de tantos brasileiros, que a honraram e, ainda, a honram, com suas preciosas projeções 
intelectuais nos planos jurídico e institucional, dela fazendo, sem rodeios, a principal Casa de Direito das Américas.

Muito se espera, pois, nessa área, de nossa Faculdade, que, por certo, continuará a emprestar sua colaboração nesse processo de integração, propiciando meios aos interessados para que se desenvolvam e se engajem nessa eterna batalha pelo predomínio do Direito, domando-se a tecnologia em prol da defesa da dignidade humana. Conservar-se-á, assim, como centro irradiador de cultura e de soluções práticas, para os problemas que se oferecerem na realização da justiça e da harmonia, que devem imperar no relacionamento social, que são, aliás, fins últimos do próprio Direito!... 